\title{
Distribution of Virulence Plasmids within Salmonellae
}

\author{
By M. J. WOODWARD,* I. MCLAREN AND C. WRAY \\ Department of Bacteriology, Ministry of Agriculture, Fisheries and Food, Central Veterinary \\ Laboratory, New Haw, Weybridge, Surrey KT15 3NB, UK
}

(Received 11 August 1988; revised 26 October 1988; accepted 7 November 1988)

\begin{abstract}
The virulence region of the Salmonella dublin $50 \mathrm{MDa}$ plasmid shared homology with 678 of 1021 salmonellae tested in colony hybridization experiments. The majority of $S$. dublin, $S$. typhimurium and $S$. enteritidis isolates tested hybridized with the region whereas, with the exception of $S$. hessarek, $S$. pullorum and $S$. gallinarum, other serotypes did not. Homologous virulence regions were plasmid encoded. In $S$. typhimurium a common $60 \mathrm{MDa}$ plasmid was present in all phage types tested but not in DT4, DT37 and DT170. Smaller plasmids showing partial homology were found in DT12, DT18, DT193 and DT204C. In $S$. enteritidis a distinct plasmid profile for each of eight phage types was observed. Hybridizing plasmids were found in DT3, DT4, DT8, DT9 and DT11 whereas DT7, which was plasmid free, and DT10 and DT14, which harboured plasmids, did not hybridize. The extent of homology shared between $S$. dublin, $S$. typhimurium and $S$. enteritidis virulence plasmids was about $10 \mathrm{MDa}$ and appeared conserved. Virulence plasmids from $S$. typhimurium and $S$. enteritidis did not show homology with a region of the $S$. dublin $50 \mathrm{MDa}$ plasmid which was not associated with virulence functions whereas plasmids of about $24 \mathrm{MDa}$ and $38 \mathrm{MDa}$ in some $S$. typhimurium phage types did. The association of conserved virulence regions upon differing plasmids within salmonellae is discussed with reference to possible mechanisms of distribution and evolution of virulence genes.
\end{abstract}

\section{INTRODUCTION}

Salmonellosis is a continuing problem in man and animals, causing economic losses and public health concern (Wray, 1985). Plasmids harboured by salmonellae have been cited as encoding virulence functions. A $60 \mathrm{MDa}$ plasmid harboured by several Salmonella typhimurium isolates (Jones et al., 1982), a $50 \mathrm{MDa}$ plasmid harboured by $S$. dublin (Terakado et al., 1983; Baird et al., 1985; Chikami et al., 1985) and a $37 \mathrm{MDa}$ plasmid harboured by $S$. enteritidis (Nakamura et al., 1985) have been demonstrated to encode at least some virulence functions. Baird et al. (1985), by insertional mutagenesis with TnA, located virulence determinants encoded within a $10 \mathrm{MDa}$ region of the $S$. dublin and $S$. typhimurium plasmids. These regions shared sequence homology. Furthermore, Williamson et al. (1988) demonstrated that sequences common to the virulence region were found in a number of other Salmonella serotypes and these sequences were functionally interchangeable after interserotype transductions.

Certain Salmonella serotypes and indeed some subgroups within specific serotypes are prevalent in animals. For example, $95 \%$ of cattle infections are attributable to $S$. dublin and $S$. typhimurium DT204C (Wray et al., 1987). Whilst much importance is attached to biotyping (Duguid et al., 1975), phage typing (Barker et al., 1980) and plasmid profiling (Brunner et al., 1983; Holmberg et al., 1984; Wray et al., 1987) for epidemiological studies, very little is known about the distribution and spread of factors influencing pathogenicity amongst salmonellae. In order to gain clues as to the relationship between the prevalence of certain groups of salmonellae in animals and their genetic capacity for pathogenicity, salmonellae received for serological identification at the Central Veterinary Laboratory were hybridized with a $4 \mathrm{~kb}$ fragment taken from within the virulence region of the $S$. dublin $50 \mathrm{MDa}$ plasmid. Furthermore, to investigate 
the extent of homology shared between plasmids from different serotypes, sequences flanking the $4 \mathrm{~kb}$ virulence probe were used to hybridize Southern transfers of restriction digests of representative plasmids. As far as the mechanism of distribution of homologous virulence regions is concerned, an active spread by mobile vectors such as conjugative plasmids, bacteriophages and transposons, or a passive mechanism of evolution from a common ancestor, may be involved (Farrar, 1983). Assuming that presence or absence of homologous sequences on the plasmids carrying the virulence region might indicate a common evolution or an active spread respectively, the salmonellae were also hybridized with a non-virulence region derived from the $S$. dublin $50 \mathrm{MDa}$ plasmid. This paper presents our initial findings.

\section{METHODS}

Bacterial strains, plasmids and plasmid vectors. These are listed in Table 1. Escherichia coli strains were stored in brain heart infusion broth supplemented with $15 \%(\mathrm{v} / \mathrm{v})$ glycerol at $-70^{\circ} \mathrm{C}$, after Silhavy et al. (1984). Salmonella strains were stored on Dorset egg slopes (PM5p; Oxoid) at room temperature. Bacteria were grown in complete medium (Alaeddinoglu \& Charles, 1979) supplemented as described in the text.

Conjugation. The membrane filter mating described by Willetts (1984) was used.

Transposon tagging and curing of plasmids. In order to make a plasmid-free $S$. dublin derivative, the 50 MDa plasmid of $S$. dublin 1447/86 was tagged with Tn5.751 using the methods of Rella et al. (1985). Curing of the tagged plasmid was done by SDS and acridine orange treatment as described by Tomoeda et al. (1968) and Salisbury et al. (1972), respectively, and searching for kanamycin-sensitive clones by replica plating.

DNA manipulations. Crude plasmid DNA for profiling and Southern transfers was prepared by the method of Birnboim \& Doly (1979). Plasmid DNA for cloning and detailed restriction mapping was further purified by centrifugation to equilibrium in a $\mathrm{CsCl} /$ ethidium bromide gradient (Maniatis et al., 1982) for $5 \mathrm{~h}$ at $20^{\circ} \mathrm{C}$ in a Beckman TL100 benchtop ultracentrifuge. $\mathrm{CsCl}$ and ethidium bromide were removed by the method of Grinsted \& Bennett (1984). The method of Dazins et al. (1985) was used to prepare whole-cell DNA. Restriction digests,

\section{Table 1. Strains, plasmids and plasmid vectors}

Strain, plasmid, vector

Salmonella strains

Wild-type salmonellae

S. dublin $1447 / 86$

S. dublin 1447/86(pME9)

S. dublin $1447 / 86(\mathrm{p}:: \operatorname{Tn} 5.751)$

S. dublin $1447 / 86 \mathrm{p}^{-}$

E. coli $\mathrm{K} 12$ strains

ED8654

39R861

DH5 alpha

Plasmids

pME9

pVW 1

pVW22

pVW23

pVW25

pVW26

pVW27
Properties

Field isolates

Field isolate from bovine salmonellosis

$50 \mathrm{MDa}$ virulence plasmid tagged with Tn5.751

Plasmid-free derivative

$\mathrm{F}^{-}$metB supE supF $h s d M^{+} h s d R$

Strain carrying reference plasmids of known size

$\mathrm{F}^{-}$end $\mathrm{Al}$ hsdRI7 $\left(\mathrm{r}^{-} \mathrm{m}^{-}\right)$supE44 thi-I recAI gyrA96 relAI $\phi 80 \mathrm{~d} l a c Z$ M15

Cb Tc IncPl Tra Rep(ts)::Tn $5.751 \mathrm{Km}$ Tp harboured in ED8654

pBR322::Tn5; source of $X$ hol fragment encoding kanamycin resistance

pUC $8+4.0 \mathrm{~kb}$ HindIII fragment from S. dublin $50 \mathrm{MDa}$ plasmid

pUC8 $+5.6 \mathrm{~kb}$ HindIII fragment from $S$. dublin $50 \mathrm{MDa}$ plasmid pUC8 + $15 \mathrm{~kb}$ XhoI fragment from $S$. dublin $50 \mathrm{MDa}$ plasmid inserted at the SalI site

pUC8 + $16 \mathrm{~kb}$ Xhol fragment from $S$. dublin 50 MDa plasmid inserted at the Sall site

$47 \mathrm{~kb} X$ hol fragment ligated with the internal XhoI fragment of Tn5 (pVW1) encoding kanamycin resistance
Source or reference

Central Veterinary Laboratory Central Veterinary Laboratory

This work

This work

This work

Borck et al. (1976)

E. J. Threlfall, Colindale

Gibco-BRL

Rella et al. (1985)

Hirsch et al. (1986)

This work

This work

This work

This work

This work 
agarose gel electrophoresis, electroelution of DNA fragments, ligations and transformations were carried out as described by Maniatis et al. (1982).

Hybridization. Nylon filters (Amersham) were used. Lysis of colonies onto filters was as described by Mainil et al. (1985). Dot blots and Southern transfers were as described by Maniatis et al. (1982). DNA was fixed to filters by placing air-dried filters wrapped in Saran Wrap (Dowex Corp.) inverted onto a UV transilluminator for $4 \mathrm{~min}$ exposure at $302 \mathrm{~nm}$ wavelength. Prehybridization for at least $1 \mathrm{~h}$ was at $68^{\circ} \mathrm{C}$ in $6 \times \mathrm{SSC}(1 \times \mathrm{SSC}$ is $0 \cdot 15 \mathrm{M}$ $\mathrm{NaCl}, 0.015 \mathrm{M}$-sodium citrate, $\mathrm{pH} 7), 5 \times$ Denhardt's solution $[1 \times$ Denhardt's is $0.02 \%(\mathrm{w} / \mathrm{v})$ bovine serum albumin, $0.02 \%(\mathrm{w} / \mathrm{v})$ Ficoll, $0.02 \%$ polyvinylpyrrolidone] and $0.5 \%(\mathrm{w} / \mathrm{v})$ SDS containing sonicated denatured salmon sperm heterologous DNA $\left(20 \mu \mathrm{g} \mathrm{ml}^{-1}\right.$; Sigma). Probe DNA labelled to $1 \times 10^{9}$ c.p.m. $\mu \mathrm{g}^{-1}$ using the random sequence hexanucleotide labelling system of Feinberg \& Vogelstein (1983) following the manufacturer's recommendations (Multiprime, Amersham) was heat denatured $\left(100^{\circ} \mathrm{C}\right.$ for $\left.2 \mathrm{~min}\right)$ and added to the filters $(10 \mathrm{ng}$ probe DNA per filter) in fresh hybridization solution. Hybridization was overnight at $68^{\circ} \mathrm{C}$. Filters were washed at $68{ }^{\circ} \mathrm{C}$ in $2 \times \operatorname{SSC}(2 \times 15 \mathrm{~min}), 2 \times \mathrm{SSC}, 0 \cdot 1 \% \operatorname{SDS}(30 \mathrm{~min})$, and $0 \cdot 1 \times \mathrm{SSC}(30 \mathrm{~min})$ sequentially. Autoradiography of filters was for $30 \mathrm{~min}$ to $4 \mathrm{~h}$ at $-70^{\circ} \mathrm{C}$. Probe was removed by washing in $0 \cdot 4 \mathrm{M}-\mathrm{NaOH}$ at $65^{\circ} \mathrm{C}$ for at least $30 \mathrm{~min}$ followed by washing in $0.1 \times \mathrm{SSC}, 0.1 \%(\mathrm{w} / \mathrm{v}) \mathrm{SDS}, 0.2 \mathrm{M}-\mathrm{Tris} / \mathrm{HCl} \mathrm{pH} 7.5$ at $45^{\circ} \mathrm{C}$ for 30 $\min$.

\section{RESULTS \\ Preparation of probes}

Digestion of the 50 MDa plasmid of $S$. dublin 1447/87 with various restriction endonucleases gave fragments consistent with those predicted from the map of the 50 MDa plasmid of $S$. dublin 2229 (Baird et al., 1985; A. Lax, personal communication). A detailed restriction map of the 50 MDa plasmid with which we agree is to be published elsewhere (A. Lax, personal communication) and, therefore, the plasmids in $S$. dublin strains 2229 and 1447/87 were considered similar, if not identical. In order to isolate DNA fragments from the $50 \mathrm{MDa}$ plasmid for use as probes, HindIII fragments A-I (see Fig. 1) were cloned in pUC8 (Vieira \& Messing, 1982). The choice of HindIII was made because nine fragments of suitable size (1.5-18 kb) and distribution were generated, of which one, about $4 \mathrm{~kb}$ in size, was located centrally within the virulence region identified by Baird et al. (1985). Potential probes were hybridized against subcloned fragments encompassing discrete regions of the $50 \mathrm{MDa} S$. dublin $1447 / 87$ plasmid to verify site of derivation and to test for repetitive sequences. In these experiments, HindIII fragments separately were hybridized with Southern transfers of HindIII, EcoRI and SalI digests of pVW25, pVW26 and pVW27. HindIII fragments F and G hybridized with predicted fragments only, confirming their derivation and suggesting that they lacked repeated sequences. Neither fragment $F$ nor fragment $G$ hybridized with whole-cell DNA of a plasmid-free derivative of $S$. dublin 1447/87 (see Methods).

\section{Distribution of $S$. dublin 50 MDa plasmid sequences amongst salmonellae}

Baird et al. (1985) demonstrated the presence of a common $10 \mathrm{mDa}$ virulence region encoded by large but dissimilar plasmids in $S$. dublin 2229 and $S$. typhimurium M242. Williamson et al. (1988) demonstrated by colony hybridization experiments that sequences homologous to the virulence region were present in a further nine serotypes. Questions arise as to how widely distributed the virulence region is amongst salmonellae and, furthermore, what is the degree of association between the virulence region and the $S$. dublin plasmid in salmonellae other than $S$.

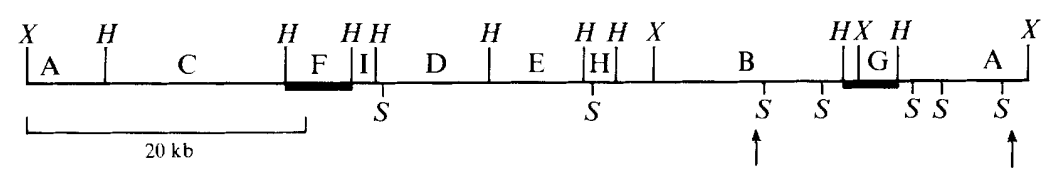

Fig. 1. Restriction map of the 50 MDa plasmid from $S$. dublin $1447 / 86$ showing the HindIII $(H)$, Sst I $(S)$ and $X h o I(X)$ sites. The extent of the virulence region as determined by Baird et al. (1985) is marked by arrows and the regions used for probe experiments are highlighted as thick lines. All HindIII fragments are designated $\mathrm{A}$ to $\mathrm{I}$ according to size, with fragment $\mathrm{A}$ the largest and fragment $\mathrm{I}$ the smallest. 
Table 2. Hybridization reaction of $S$. typhimurium isolates classified by phage type probed with $S$. dublin $50 \mathrm{MDa}$ plasmid HindIII fragments $F$ and $G$

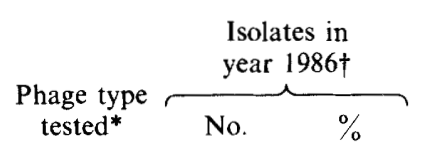

\begin{tabular}{|c|c|c|c|}
\hline 1 & & & 3 \\
\hline 2 & & & 1 \\
\hline 6 & & & 2 \\
\hline 8 & & & 1 \\
\hline 9 & 44 & 1.75 & 8 \\
\hline 12 & 121 & $4 \cdot 82$ & 50 \\
\hline 13 & & & 1 \\
\hline 18 & & & 5 \\
\hline 41 & & & 3 \\
\hline 44 & & & 2 \\
\hline 49 & 317 & 12.64 & 55 \\
\hline $49 \mathrm{~A}$ & & & 8 \\
\hline 69 & & & 1 \\
\hline 99 & & & 3 \\
\hline 103 & & & 11 \\
\hline 104 & 54 & $2 \cdot 15$ & 34 \\
\hline 107 & & & 4 \\
\hline 108 & & & 2 \\
\hline 114 & & & 3 \\
\hline 141 & & & 4 \\
\hline 195 & & & 2 \\
\hline 204 & 158 & $6 \cdot 30$ & 10 \\
\hline $204 \mathrm{~A}$ & & & 8 \\
\hline $204 \mathrm{C} \ddagger$ & 850 & $33 \cdot 9$ & 46 \\
\hline 208 & & & 4 \\
\hline 10 & 35 & 1.40 & 10 \\
\hline 40 & & & 23 \\
\hline 66 & & & 6 \\
\hline 110 & 39 & 1.55 & 34 \\
\hline 146 & & & 6 \\
\hline 160 & & & 12 \\
\hline 193 & 190 & 7.58 & 21 \\
\hline 4 & & & 2 \\
\hline 37 & & & 2 \\
\hline 170 & 61 & $2 \cdot 43$ & 17 \\
\hline
\end{tabular}

No. tested for DNA homology by hybridization

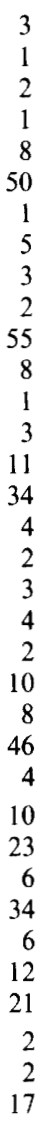

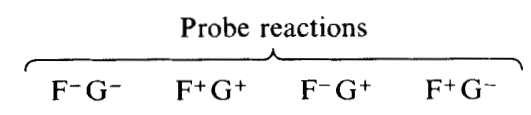

$\begin{array}{rrrl}0 & 0 & 3 & 0 \\ 0 & 0 & 1 & 0 \\ 0 & 0 & 2 & 0 \\ 0 & 0 & 1 & 0 \\ 0 & 0 & 8 & 0 \\ 3 & 3 & 44 & 0 \\ 0 & 0 & 1 & 0 \\ 0 & 0 & 5 & 0 \\ 1 & 0 & 2 & 0 \\ 0 & 0 & 2 & 0 \\ 3 & 0 & 52 & 0 \\ 0 & 0 & 8 & 0 \\ 0 & 0 & 1 & 0 \\ 0 & 3 & 0 & 0 \\ 0 & 0 & 11 & 0 \\ 0 & 0 & 34 & 0 \\ 0 & 0 & 4 & 0 \\ 0 & 0 & 2 & 0 \\ 0 & 3 & 0 & 0 \\ 0 & 0 & 4 & 0 \\ 0 & 0 & 2 & 0 \\ 0 & 5 & 5 & 0 \\ 0 & 0 & 8 & 0 \\ 0 & 20 & 26 & 0 \\ 0 & 0 & 4 & 0 \\ 9 & 0 & 1 & 0 \\ 11 & 0 & 12 & 0 \\ 5 & 0 & 1 & 0 \\ 7 & 0 & 27 & 0 \\ 1 & 2 & 1 & 2 \\ 4 & 0 & 8 & 0 \\ 4 & 7 & 10 & 0 \\ 2 & 0 & 0 & 0 \\ 2 & 0 & 0 & 0 \\ 17 & 0 & 0 & 0 \\ & & & \\ 0 & 0 & 0\end{array}$

* Representative isolates of all phage types were not tested.

$\dagger$ Number of isolates of phage types not given if less than $1 \%$ incidence amongst $S$. typhimurium.

$\ddagger$ All $204 \mathrm{C}$ isolates were of cattle origin.

dublin. To address these questions, HindIII fragments $\mathrm{F}$ and $\mathrm{G}$ were used as probes in colony hybridizations with 1021 Salmonella isolates taken from the 1986 Salmonella collection at the central Veterinary Laboratory.

Sequences homologous with the virulence region (HindIII fragment $\mathrm{G}$ ) were widespread amongst those salmonellae tested $(678 / 1021) ; 219$ of $233 \mathrm{~S}$. dublin isolates tested showed homology, as did 67 of $72 S$. enteritidis isolates and 333 of 404 S. typhimurium isolates (Table 2). $S$. hessarek (1/1), S. gallinarum (2/2) and $S$. pullorum (3/3) showed homology, whereas the following did not (number of isolates tested in parentheses): $S$. agama (15), S. agona (17), $S$. albany (1), S. amager (1), S. anatum (18), S. arizonae (1), S. bareilly (1), S. berta (1), S. binza (1), S. bovis-morbificans (2), S. brandenburg (1), S. bredeney (11), S. cerro (1), S. cholerae-suis var. kunzendorf (1), S. cubana (1), S. derby (13), S. durham (1), S. give (11), S. goldcoast (1), S. haifa (1), $S$. hardar (10), S. havana (1), S. illinois (1), S. indiana (14), S. infantis (12), S. kedougou (12), S. kentucky (1), S. livingstone (11), S. liverpool (1), S. london (1), S. manhattan (1), S. mbandaka (11), S. meleagridis (2), S. montevideo (15), S. muenchen (1), S. munster (1), S. newport (28), S. poona (1), 
S. ohio (2), S. oranienberg (3), S. saint-paul (5), S. schwarzengrund (1), S. senftenberg (11), S. stanley (17), S. tado (1), S. taksony (1), S. tennessee (10), S. thielalee (11), S. virchow (16), S. worthington (13), S4 : $12: \mathrm{D}(10)$.

Sequences homologous with a non-virulence region (HindIII fragment F) were less widely spread amongst those salmonellae tested $(265 / 1021) ; 219$ S. dublin, 45 S. typhimurium and one $S$. berta showed homology. Interestingly, of the 265 isolates positive for probe $\mathrm{F}$ (non-virulence), all except two were also positive for probe $\mathrm{G}$ (virulence); a not unexpected finding if the same plasmid was involved. Of six S. typhimurium DT146 isolates, two hybridized with F but not G (Table 2). This finding contra-indicated, suggesting that these regions possibly resided on separate replicons.

\section{$S$. dublin 50 MDa plasmid HindIII fragments $F$ and $G$ hybridized with dissimilar plasmids in salmonellae other than $S$. dublin}

To determine the location of homologous sequences, probes $F$ and $G$ were hybridized in separate experiments with Southern transfers of plasmid profiles of $47 \mathrm{~S}$. dublin and 71 nondublin salmonellae. The results are considered below.

Significant among $S$. typhimurium infections of cattle is phage type DT204C; 52\% of our isolates in 1986 were of this phagetype. Wray et al. (1987) have differentiated DT204C isolates on the basis of plasmid profile patterns. Southern transfers of one representative of each of 24 established plasmid profiles were hybridized in separate experiments with probes $F$ and $G$. The virulence region (probe $\mathrm{G}$ ) shared homology with a plasmid of about $60 \mathrm{MDa}$ in each of 23 isolates and of about $50 \mathrm{MDa}$ in one isolate. Other plasmids which were present in the profiles, including the $120 \mathrm{MDa}$ incH2 multiple resistance plasmid (Threlfall et al., 1986) present in all DT204C isolates, did not hybridize with the virulence region. Probe F hybridized with 10 of the 24 profiles. The plasmids sharing homology were of approximately $38 \mathrm{MDa}$ in six of the strains and $24 \mathrm{MDa}$ in four.

Other prevalent $S$. typhimurium isolates in 1986 belonged to phage types DT9, 10, 12, 49, 104 , 110,170 and 193 (Table 2). The virulence region (probe $G$ ) again shared homology with a large plasmid of about $60 \mathrm{MDa}$ in those $S$. typhimurium isolates positive in colony hybridization tests. Most $S$. typhimurium isolates had several other plasmids but these did not hybridize with the virulence region. One isolate of phage type DT 18 harboured a hybridizing plasmid of about 90 $\mathrm{MDa}$. Probe $\mathrm{F}$ shared homology with plasmids of about $24 \mathrm{MDa}$ harboured in $3 / 3 \mathrm{~S}$. typhimurium DT99 and of about $38 \mathrm{MDa}$ harboured in 1/3 S. typhimurium DT12 and 1/3 $S$. typhimurium DT146 isolates. Hybridization of probe F with other plasmids was not observed.

$S$. enteritidis is of increasing concern in man and animals as a major cause of salmonellosis and, in particular, poultry are considered a common source of human infection. In our experiments, of 24 S. enteritidis plasmid profiles tested by Southern hybridization (Fig. 2), the virulence region hybridized with one discrete large plasmid harboured in isolates of phage types DT3, DT4, DT8, DT9 and DT11. Interestingly, phage types DT10 and DT14, each of which harboured a single large plasmid, and phage type DT7, which was plasmid-free, failed to hybridize even at lower stringencies. Within any one phage type the same size of plasmid was repeatedly observed but between phage types there was considerable size variation. Plasmids of approximately $35 \mathrm{MDa}$ were found in DT4, of $55 \mathrm{MDa}$ in DT3, DT9, DT11 and DT14, and of 60 MDa in DT8, whereas an untypable strain harboured two plasmids of $40 \mathrm{MDa}$ and $60 \mathrm{MDa}$, both of which hybridized (Fig. 2). Probe F did not hybridize with any $S$. enteritidis plasmids.

Of $47 \mathrm{~S}$. dublin isolates positive in colony hybridization tests taken from British outbreaks of calf salmonellosis occurring at different geographical locations during 1986, all harboured a single $50 \mathrm{MDa}$ plasmid which hybridized with both probes. Furthermore, they all shared a common restriction pattern identical to $S$. dublin $1447 / 87$ (see above). Isolates of continental origin dating back to 1972, however, showed variation in size and restriction pattern (unpublished) but, importantly, hybridized with probe $\mathrm{G}$ only.

Virulence plasmids in S. dublin, S. typhimurium and S. enteritidis share extensive homology

The question arose as to the extent of homology shared between plasmids hybridizing with the virulence region probe. Baird et al. (1985) demonstrated a tract of DNA covering the virulence 


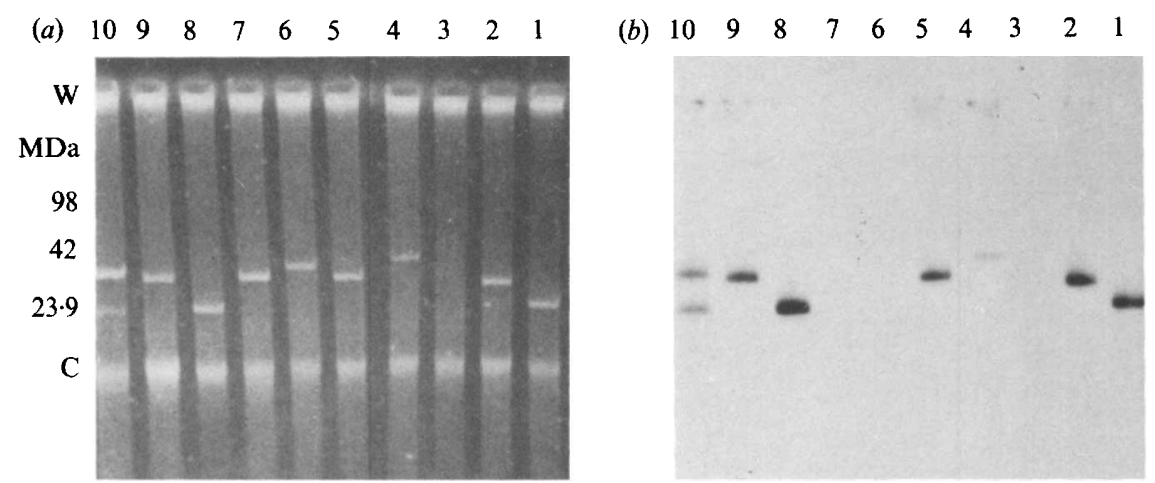

Fig. 2. (a) Plasmid profiles of ten $S$. enteritidis isolates of animal origin belonging to phage types DT4 (lane 1), DT3 (lane 2), DT7 (lane 3), DT8 (lane 4), DT9 (lane 5), DT10 (lane 6), DT14 (lane 7), DT4 of human origin (lane 8), DT11 (lane 9) and an untypable strain (lane 10). The distances migrated of plasmids of known molecular mass are marked. Wells are marked 'W' and chromosomal DNA is indicated by ' $C$ '. (b) Autoradiograph of a Southern transfer of the plasmid profiles from $(a)$ after hybridization with probe $\mathrm{G}$, the virulence region of the $S$. dublin $50 \mathrm{MDa}$ plasmid.

region of about $10 \mathrm{MDa}$ in size common to the $50 \mathrm{MDa}$ plasmid of $S$. dublin 2229 and to the 60 MDa plasmid of S. typhimurium 1275 as judged by restriction endonuclease digest patterns and limited hybridization experiments. To extend these findings, plasmids from $30 \mathrm{~S}$. typhimurium isolates of phage types DT12, DT18, DT99, DT104, DT193 and DT204C, and from $7 S$. enteritidis isolates of phage types DT3, DT4, DT8, DT9, DT10, DT11 and one untypable strain (harbouring two hybridizing plasmids), were digested with HindIII and SstI together, transferred to filters and hybridized with virulence region probes. The choice of HindIII/SstI cuts was made to aid comparison with the known map of the $S$. dublin $50 \mathrm{MDa}$ plasmid (Fig. 1). In each test, when HindIII fragment $\mathrm{G}$ alone was used as probe, a single hybridization signal was located to a fragment with a mobility of about $4 \mathrm{~kb}$ identical to that of fragment $\mathrm{G}$ of HindIII-cut $S$. dublin $50 \mathrm{MDa}$ plasmid. Here was evidence of conservation of this particular sequence between serotypes. After verification that vector pUC8 DNA did not hybridize with plasmids of $S$. dublin, $S$. typhimurium and $S$. enteritidis, linearized $\mathrm{pVW} 25$ and $\mathrm{pVW} 26$ together were labelled and used to probe the same filters (Fig. 3). Consistent hybrization patterns were observed for all $S$. enteritidis phage types tested, irrespective of the size of the plasmid in any one phage type. Fragments showing homology were about $1 \cdot 8,4 \cdot 0,6 \cdot 5,7 \cdot 5,8 \cdot 5$ and $12 \mathrm{~kb}$ in size. Consistent hybridization patterns were also observed for all $S$. typhimurium phage types tested. Fragments showing homology were about $1 \cdot 8,4 \cdot 0,6 \cdot 0$ (weak signal), 6.5, 7.5, 8.5 and $14 \mathrm{~kb}$ in size. In view of the high stringency of the hybridization procedure and the commonality between S. dublin, S. typhimurium and S. enteritidis of hybridizing fragments of about $1 \cdot 8,4.0$ and $8.5 \mathrm{~kb}$, a high degree of conservation of DNA associated with virulence functions is strongly supported.

\section{DISCUSSION}

Virulence regions on plasmids in salmonellae have been described previously (Jones et al., 1982; Terakado et al., 1983; Baird et al., 1985; Chikami et al., 1985; Williamson et al., 1988). We have shown these regions to be widespread amongst $S$. dublin, $S$. typhimurium and $S$. enteritidis. Elimination of these plasmids does not cause absolute loss of virulence (Baird et al., 1985). Also, other prevalent serotypes such as $S$. anatum, $S$. indiana, $S$. montevideo and $S$, virchow lack these virulence regions. This strongly supports the contention that virulence of salmonellae is multifactorial and different mechanisms of pathogenesis are encoded by different groups of Salmonella.

Helmuth et al. (1985) suggested that a given serotype would contain a serotype-specific virulence plasmid in the majority of isolates. Over $90 \%$ of $S$. dublin isolates tested hybridized with the virulence region. It is possible that the $50 \mathrm{MDa}$ virulence plasmid was lost from some 


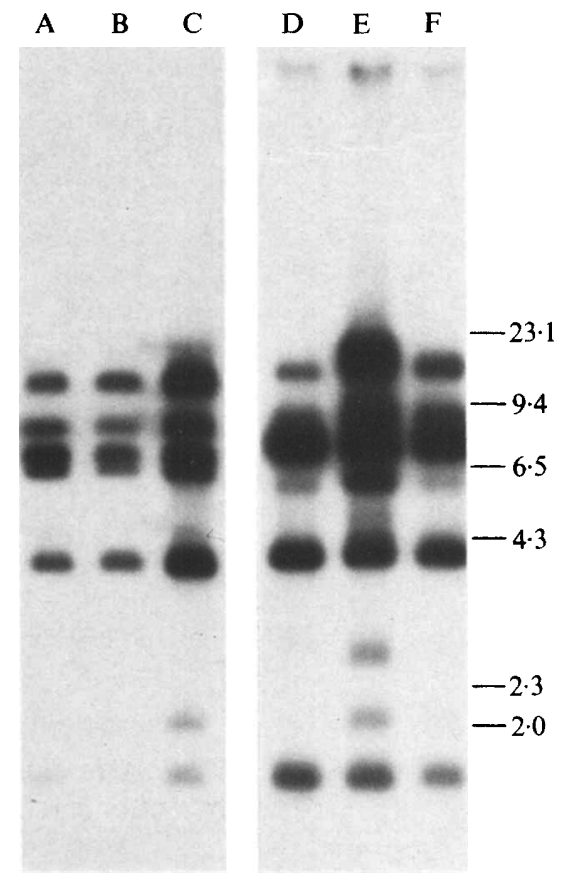

Fig. 3. Autoradiograph of ${ }^{32} \mathrm{P}-$ labelled linearized pVW25 and pVW26 DNA probed against Southern transfers of HindIII/SstI digests of plasmid DNA extracted from $S$. enteritidis phage types DT3 (lane A), DT4 (lane B) and DT8 (lane C), and from S. typhimurium phage types DT104 (lane D), DT204C profile E (lane E) and DT99 (lane F). The sizes (kb) of $\lambda$ HindIII fragments are marked.

isolates upon storage or that plasmid-free strains were relatively common. Whether those nonhybridizing $S$. dublin isolates were as virulent as those which hybridized is open to speculation. No differences between restriction pattern of the common $50 \mathrm{MDa}$ plasmid in $S$. dublin of cattle origin were observed, suggesting conservation of this plasmid and possible clonal spread of $S$. dublin in Great Britain. The majority of $S$. typhimurium phage types conform to the hypothesis of Helmuth et al. (1985); some phage types, notably DT104, showed $100 \%$ carriage of the virulence plasmid whilst phage type DT 40 showed $50 \%$ carriage and phage type DT 170 showed $0 \%$ carriage. The question arises as to the fundamental differences between DT170, DT40 and other S. typhimurium phage types such that the virulence plasmid appears to be dispensable in one group but obligatory in another group. Each phage type of $S$. enteritidis tested, with the exception of DT7, possessed a single large plasmid the size of which correlated with phage type. However, only plasmids in phage types DT3, DT4, DT8, DT9 and DT11 hybridized with the virulence region whereas plasmids in DT10 and DT14 did not. Whether the non-hybridizing plasmids encode distinct virulence functions is open to speculation.

Similarity of plasmid size in any one serotype or phage type does not necessarily imply physical or genetic relatedness. However, probes $F$ and $G$, each from physically well separated regions of the $S$. dublin plasmid and comprising some $9 \mathrm{~kb}$ in total, hybridized with $50 \mathrm{MDa}$ plasmids in each of $47 \mathrm{~S}$. dublin isolates, implying conservation. Interestingly, homology with probe F was shown by 38 MDa plasmids in $S$. typhimurium phage types DT12 (1/3), DT146(1/3) and DT204C (6/24) and by 24 MDa plasmids in $S$. typhimurium DT99 (3/3). Here was evidence of disassociation between sequences contiguous on the $S$. dublin $50 \mathrm{MDa}$ plasmid.

Southern blots of HindIII/Sst I cuts of virulence plasmids from $S$. typhimurium and $S$. enteritidis showed considerable homology with the $S$. dublin $50 \mathrm{MDa}$ plasmid and conservation of restriction fragments around the virulence probe $G$ region. Williamson et al. (1988) demonstrated interserotype transduction of functional virulence regions between $S$. dublin and $S$. typhimurium, thus extending the findings of Baird et al. (1985) that virulence regions in these 
two serotypes were structurally very similar. What is surprising is the similarity of virulence regions of $S$. dublin and S. typhimurium with those on plasmids in S. enteritidis, in view of their considerable variation in size and restriction pattern (Williamson et al., 1988; unpublished observation). Relatively few $S$. enteritidis plasmids have been analysed in detail and there may be a number of subsets of plasmids sharing homology; phage types DT3, DT4, DT8, DT9, DT11 and perhaps some others belong to one subset related to the $S$. dublin and $S$. typhimurium virulence plasmids. Whilst the Southern blot data indicate significant homology between virulence regions of $S$. dublin, $S$. typhimurium and $S$. enteritidis it is possible that only small regions within any hybridizing fragment shared the homology. Furthermore, considering the size of the probes pVW25 and pVW26, repeated sequences are likely to contribute to apparent homology. Whether the hybridizing sequences are contiguous is unknown.

\section{REFERENCES}

Alaeddinoglu, N. G. \& Charles, H. P. (1979) Transfer of a gene for sucrose utilization into Escherichia coli $\mathrm{K} 12$, and consequent failure of expression of genes for D-serine utilization. Journal of General Microbiology 110, 47-59.

Baird, G. D., Manning, E. J. \& Jones, P. W. (1985). Evidence for related virulence sequences in plasmids of Salmonella dublin and Salmonella typhimurium. Journal of General Microbiology 131, 1815-1823.

Barker, R., Old, D. C. \& Sharp, J. C. M. (1980). Phagetype/biotype groups of $S$ typhimurium in Scotland 1974-6: variation during spread of epidemic clones. Journal of Hygiene 84, 115-125.

BIRnBoim, H. C. \& Doly, J. (1979). A rapid alkaline procedure for screening recombinant plasmid DNA. Nucleic Acids Research 7, 1513-1523.

Borck, K., Beggs, J. D., Brammar, W. J., Hopkins, A. S. \& Murray, N. E. (1976). The construction in vitro of transducing derivatives of phage lambda. Molecular and General Genetics 146, 199-207.

Brunner, F., Margadant, A., Peduzzi, R. \& Piffaretti, J. C. (1983). The plasmid pattern as an epidemiological tool for $S$. typhimurium epidemics: comparison with lysotypes. Journal of Infectious Disease 148, 7-11.

Chikami, G. K., Fierer, J. \& Guiney, D. G. (1985). Plasmid-mediated virulence in Salmonella dublin demonstrated by use of a Tn5-oriT construct. Infection and Immunity 50, 420-424.

Dazins, A., Nixon, L. L., Vanags, R. I. \& ChakraBARTY, A. M. (1985). Cloning of Escherichia coli and Pseudomonas aeruginosa phosphomannose isomerase genes and their expression in alginate-negative mutants of Pseudomonas aeruginosa. Journal of Bacteriology 161, 249-257.

Duguid, J. P., Anderson, E. S., Alfredsson, G. A., BARKER, R. \& OLD, D. C. (1975). A new biotyping scheme for $S$. typhimurium and its phylogenetic significance. Journal of Medical Microbiology 8, 149166.

FARRAR, W. E. (1983). Molecular analysis of plasmids in epidemiologic investigation. Journal of Infectious Diseases 148, 1-6.

Feinberg, A. P. \& Vogelstein, B. (1983). A technique for radiolabelling DNA restriction endonuclease fragments to high specific activity. Analytical Biochemistry 132, 6-13.

Grinsted, J. \& BENNETT, P. M. (1984). Isolation and purification of plasmid DNA. Methods in Microbiology 17, 123-131.
Helmuth, R., Stephan, R., Bunge, C., Hoog, B., Steinbeck, A. \& Bulling, E. (1985). Epidemiology of virulence-associated plasmids and outer-membrane protein patterns within seven common $\mathrm{Sal}$ monella serotypes. Infection and Immunity 48, 175182.

Hirsch, P. R., Wang, C. L. \& Woodward, M. J. (1986). Construction of a Tn 5 derivative determining resistance to gentamicin and spectinomycin using a fragment cloned from R1033. Gene 48, 203209.

HolmberG, S. D., WaChSmuth, I. K., HickmanBrenner, F. W. \& Cohen, M. L. (1984). Comparing plasmid profile, phagetyping and antimicrobial susceptibility testing in characterization of S. typhimurium isolates from outbreaks. Journal of Clinical Microbiology 19, 100-104.

Jones, G. W., Rabert, D. K., Svinarich, D. M. \& Whitfield, H. J. (1982). Association of adhesive, invasive and virulent phenotypes of $S$. typhimurium with autonomous 60-megadalton plasmids. Infection and Immunity 38, 476-486.

Mainil, J., BeX, F., Couturier, M. \& KaEckenBEECK, A. (1985). Hybridization of bovine enterotoxigenic Escherichia coli with two heat-stable enterotoxin gene probes. American Journal of Veterinary Research 46, 2582-2584.

Maniatis, T., FritsCh, E. F. \& SAMbrook, J. (1982). Molecular Cloning, a Laboratory Manual. Cold Spring Harbor, NY: Cold Spring Harbor Laboratory.

Nakamura, M., Sato, S., Ohya, T., Suzuki, S. \& IKEDA, S. (1985). Possible relationship of a 36megadalton Salmonella enteritidis plasmid to virulence in mice. Infection and Immunity 47, 831-833.

Rella, M., Mercenier, A. \& HAAS, D. (1985). Transposon insertion mutagenesis of Pseudomonas aeruginosa with a $\operatorname{Tn} 5$ derivative: application to physical mapping of the arc gene cluster. Gene 33, 293-303.

Salisbury, V., Hedges, R. W. \& Datta, N. (1972). Two modes of curing transmissible bacterial plasmids. Journal of General Microbiology 70, 443-452.

Silhavy, T. J., Berman, M. L. \& Enquist, L. W. (1984). Experiments with Gene Fusions. Cold Spring Harbor, NY: Cold Spring Harbor Laboratory.

Terakado, N., Sekizaki, T., Hashimoto, K. \& NAITOH, S. (1983). Correlation between the presence of a fifty-megadalton plasmid in Salmonella dublin and virulence for mice. Infection and Immunity 41, 443-444. 
Threlfall, E. J., Rowe, B., Ferguson, J. L. \& Ward, L. R. (1986). Characterization of plasmids conferring resistance to gentamicin and apramycin in strains of Salmonella typhimurium phage type $204 \mathrm{C}$ in Britian. Journal of Hygiene 97, 419-426.

Tomoeda, M., InuzuKa, M., Kubo, N. \& NaKamura, S. (1968). Effective elimination of drug resistance and sex factors in $E$. coli by sodium dodecyl sulfate. Journal of Bacteriology 95, 1078-1089.

Vieira, J. \& Messing, J. (1982). The pUC plasmids, an M13mp7-derived system for insertion mutagenesis and sequencing with synthetic universal primers. Gene 19, 259-268.
WILLETTS, N. (1984). Conjugation. Methods in Microbiology 17, 33-59.

Williamson, C. M., Baird, G. D. \& Manning, E. J. (1988). A common virulence region on plasmids from eleven serotypes of Salmonella. Journal of General Microbiology 134, 975-982.

WRAY, C. (1985). Is salmonellosis still a serious problem in veterinary practice? Veterinary Record 116, 485-489.

Wray, C., Mclaren, I., Parkinson, N. M. \& BEEDELL, Y. (1987). Differentiation of Salmonella typhimurium DT204C by plasmid profile and biotype. Veterinary Record 121, 514-516. 